\title{
KANAUJI OF KANPUR: A BRIEF OVERVIEW
}

\author{
Pankaj DWIVEDI \\ Indian Institute of Technology Ropar \\ pankajd@iitrpr.ac.in
}

\author{
Somdev KAR \\ Indian Institute of Technology Ropar \\ somdev.kar@iitrpr.ac.in
}

\begin{abstract}
Hindi, in its totality, refers to a dialect continuum spoken mainly across northern India. This continuum is usually divided into two forms: Eastern and Western Hindi. Eastern Hindi is mainly made up of Awadhi, Chhattisgarhi and Bagheli dialects, while Western Hindi consists of Hindostani, Banagru, Braj Bhaka, Bundeli and Kanauji dialects.

After Linguistic survey of India (1894-1928) by George A. Grierson - there has been little or no work which specifically focuses on Kanauji. Trivedi $(1993,2005)$ and Mishra and Bali $(2010,2011)$ report some secondary data from Kanauji in their works, their focus of inquiry is not Kanauji though. Lewis, Simons \& Fennig (2013) refers Kanauji as a language with very low identity.

This paper attempts to study the current sociolinguistic situation of Kanauji spoken in the Kanpur district of Uttar Pradesh (India). Some other goals of the paper are following: 1) to feel the pulse of language attitude, with reference to standard Hindi, of the people in Kanpur 2) to present basic linguistic information and 3) to direct attention of the other linguists to Kanauji, which unfortunately has not been the case so far despite of it being mother tongue of millions.

This study is result of eighteen days of a fieldtrip to Kanpur district and subsequent preparation of a small speech database of Kanauji. Importance of the work lies in the fact that no previous work, which specifically focuses on Kanauji, has been published so far. This is true at least in the open literature.
\end{abstract}

Keywords: Kanauji; language endangerment; sociolinguistics; Tirhari; varieties of Hindi

\section{Povzetek}

Ime hindski jezik se nanaša na kontinuum dialektov v severni Indiji. Zanj je značilna delitev na dve obliki: vzhodni in zahodni hindski jezik. Vzhodni hindski jezik sestavljajo dialekti Awadhi, Chhattisgarhi in Bagheli, zahodnega pa Hindostani, Banagru, Braj Bhaka, Bundeli in dialekti Kanauji.

Po jezikovnem pregledu v Indiji (Linguistic survey of India), ki ga je med leti 1894 in 1928 spisal George A. Grierson, se nihče več ni lotil raziskovanja dialekta Kanauji. Trivedi $(1993,2005)$ ter Mishra in Bali $(2010,2011)$ o njemu sicer poročajo, vendar je dialekt omenjen le posredno. Lewis in drugi (2013) ga omenjajo kot jezik z zelo slabo identiteto.

Članek je študija o trenutni sociolingvistični situaciji dialekta Kanauji, govorjenega na območju Kanpur v Uttar Pradesh v Indiji. Obenem si avtorja postavljata tudi naslednje cilje: 1 . zaznati odnos naravnih govorcev do lastnega dialekta kot tudi do standardnega jezika, 2. predstaviti osnovne 
jezikovne informacije dialekta in 3. povečati zanimanje jezikoslovcev za dialekt Kanauji, ki je bil do sedaj zelo zapostavljen kljub temu, da ima več milijonov naravnih govorcev.

Ta študija je rezultat 18-dnevnega dela na terenu na območju Kanpur in kasnejše priprave podatkovne zbirke dialekta Kanauji. Pomembnost tega dela je predvsem $v$ tem, da je ta raziskava edinstvena kar zadeva dialekt Kanauji, vsaj v javno dostopni znantveni literaturi.

Ključne besede: dialekt Kanauji; ogroženost jezika; sociolingvistika; Tirhari; raznolikost hindskega jezika

\section{Introduction}

Kanauji ${ }^{1}$ (ISO 639-3 "bjj", written in Devnagri script as कन्रोजी and pronounced as /kən.no.dzi//) is a little known dialect ${ }^{2}$ of Hindi and is hardly documented. It takes its name from town of Kanauj - the historic and one of the oldest cities dating back to ancient India. However, the language is not merely confined to district/town of Kanauj. Kanauj is a home to rich archeological and cultural heritage sites. History of Kanauj is believed to run as long as to the time of Mahabharta ${ }^{3}$. The ancient name of this place is Kanyakubja or Mahodya (Balmiki Ramayana, Mahabharata and Puran) and only later on the name Kanyakubja changed to Kannauj, the present name of the district.

In the legendary work Linguistic Survey of India written by George A. Grierson, Kanauji is classified under Western Hindi dialects together with four other dialects, namely, Hindostani, Banagru, Braj Bhaka and Bundeli (Grierson, 1916). Grieson considers Kanauji merely as a form of $\mathrm{Braj}^{4}$ Bhakha and defines its area as east-central Doab ${ }^{5}$ and country to its north. Apart from referring to it as a dialect of Western Hindi, in history or literary genre of Hindi language (Manuel, 1989), there are a few census related and other survey reports which have used the term Kanauji to refer to the Kanauji speaking population and not the dialect itself. According to Ethnologue (2013), Kanauji is presently, in its various forms, spoken in Kanpur, Farrukhabad, Etawah, Hardoi, Shahjahanpur, Pilibhit, Mainpuri, and Auraiya districts of Uttar Pradesh. However, the variety spoken in the district of Kanauj and Farrukhabad is referred as a standard one. Kanauji is usually divided into three forms: Kanauji Proper (standard

\footnotetext{
${ }^{1}$ Kanauji has been also spelled as Kannauji, Kanaoji or Kannoji by some authors and some scholars. Pankaj Dwivedi, one of the authors, is a native speaker of Kanauji spoken in Kanpur.

${ }^{2}$ Use of the term dialect here is only for the linguistic purpose, i.e., a linguistic variety. It does not allow for any sociolinguistic connotations such as standard language vs. dialect.

${ }^{3}$ Mahabharata/məhab ${ }^{\text {hartz/ }}$ is one of most important classical epics of Hindus. Its exact historical period is unclear. However, many historians date it as early as 10 century BCE, the Iron Age. Ramayana (balmiki ramajənə) and Purans (porans) are also very significant religious scriptures in Hinduism.

${ }^{4}$ Alternative spelling for Braj is Brij. Both spellings are duly accepted by several scholars.

${ }^{5}$ Doab, in Hindi, refers to plains of Ganga River. The term has been used by several authors including by George A. Grierson in Linguistic Survey of India.
} 
Kanauaji), Tirhari, and Transitional Kanauji (Lewis et al., 2013). It is spoken by more than six million people in total.

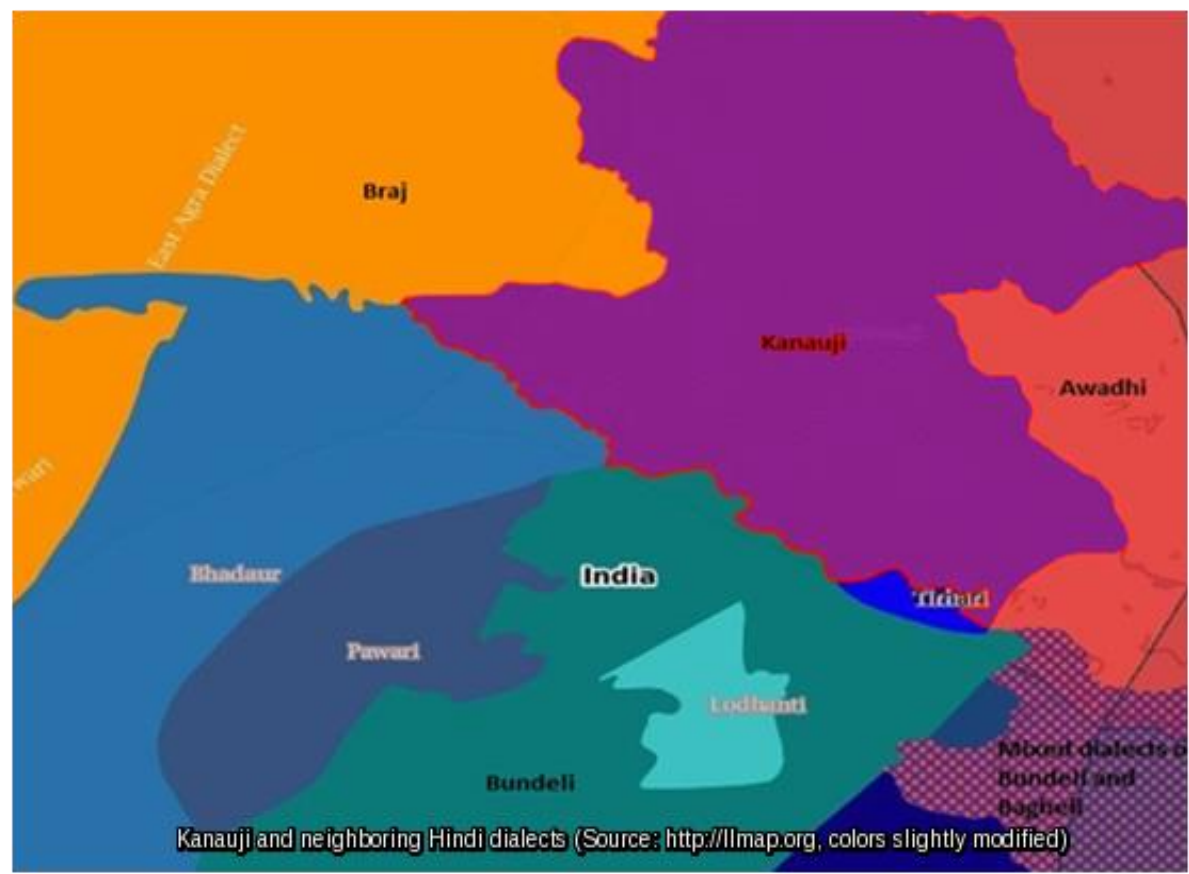

Figure 1: Distribution of the Kanauji dialect.

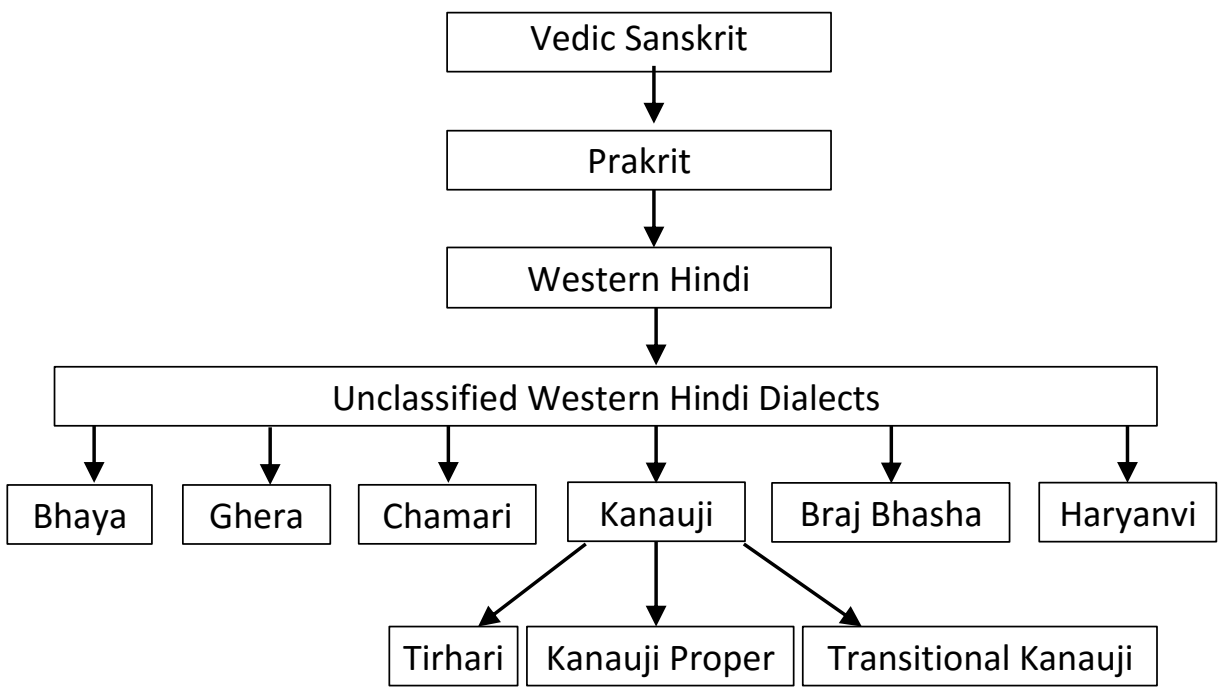

Figure 2: Evolution of the Kanauji dialect. 


\section{Kanpur and its linguistic demography}

The term Kanpur is used to refer to Kanpur Nagar ${ }^{6}$ (coordinates $\left.26^{\circ} 27^{\prime} 36^{\prime \prime} \mathrm{N}, 80^{\circ} 19^{\prime} 48^{\prime \prime} \mathrm{E}\right)$ and Kanpur Dehat ${ }^{7}\left(26^{\circ} 20^{\prime} 39.48^{\prime \prime} \mathrm{N}, 79^{\circ} 58^{\prime} 1.85^{\prime \prime} \mathrm{E}\right)$. It is the biggest city of the state of Uttar Pradesh and makes the main centre of commercial and industrial services. Kanpur Nagar (urban Kanpur) comprises of three subdistricts: Kanpur, Bilhaur, and Ghatampur, whereas Kanpur Dehat is made of five subdistricts: Akbarpur, Bhogani, Derapur, Rasulabad, and Sikandara. According to the 2011 census report, the total population of the Kanpur (both Nagar and Dehat) is estimated to be $6,368,043$. A summary of the demographic information is presented in Table 1.

Table 1: Demographic summary of district Kanpur (taken from www.censusindia.gov.in).

\begin{tabular}{||l|c|c|c|c|c||}
\hline District Name & $\begin{array}{c}\text { Total } \\
\text { Population }\end{array}$ & $\begin{array}{c}\text { Sex } \\
\text { Ratio }\end{array}$ & Density & $\begin{array}{c}\text { Child } \\
\text { Population }\end{array}$ & $\begin{array}{c}\text { Literacy Rate: } \\
\text { M/ F }\end{array}$ \\
\hline Kanpur Nagar & $1,795,092$ & 852 & 1449 & 484,529 & $85.27 / 76.89$ \\
\hline Kanpur Dehat & $4,572,951$ & 862 & 594 & 243,919 & $85.07 / 68.48$ \\
\hline
\end{tabular}

Kanauji of Kanpur is surrounded by at least four different dialects of Hindi. To the east of Kanpur, there is a district of Unao, where a variety of Awadhi is spoken; whereas, in order from north to west lie Hardoi, Kannauj and Auraiya respectively. In each of these places Kanauji is spoken; however, the variety spoken in Kannauj is considered to be the standard. To the south-east of Kanpur, between the plains of the River Ganga and Yamuna the district of Fatehpur is situated. Its northern region and language is influenced by "Awadhi" while the southern part shows effect of the "Bundeli". District of Hamirpur and Jalaun lie to the south and south-west of the Kanpur. The linguistic variety spoken in Hamirpur and Jalaun is Tirhari - the language of the river bank (Grierson, 1916). Both of these places are heavily affected by Bundeli and Bagheli. Tirhari of Hamirpur also carries a considerable touch of the Eastern Hindi.

\section{Earlier works}

Kanauji has little amount of literature to its credit and that too is available only in broken form. Some amount of folk literature and folk songs are found and preserved by the people in form of local oral literary traditions (Trivedi, 1997). The main reason for this ignorance could be the supremacy of languages like Braj and Awadhi, which

\footnotetext{
6 "Kanpur Nagar" refers to an area of Kanpur district. The term literary translates into "Kanpur City". However, Kanpur Nagar, unlike the name suggests, does have villages and rural areas.

${ }^{7}$ Kanpur Dehat refers an area of Kanpur District. The term literary translates into "Kanpur village". However, Kanpur Dehat, unlike the name suggests, does have city like towns.
} 
were established with the purpose of literary creativeness. Supremacy of Braj and Awadhi is mainly due to religious and historical beliefs of people ${ }^{8}$. Along the same line, George A. Grierson (1890) reports that, as a literary language, Kanauji had been overshadowed by its more powerful neighbor Braj Bhakha. Most of the authors (of Kanauji language area) were Muslims and they wrote in Arabic and Persian. Among Hindu and Muslims authors writing in a vernacular, that is Kanauji, was not favorable. Grierson further mentions the authors from Tikampur/Tikawanpur town of Kanpur district, who lived in mid $17^{\text {th }}$ century, such as Chintamani Tripathi, Matiram Tripathi, Bhushan Tripathi and Nilkanth Tripathi (Keay, 1933; Upadhyaya, 1934). They were siblings and together they published numerous works. All of them were patronized as poets in courts of many Mughal and Hindu Kings such as Shah Jahan, Aurangzeb, Shiv Raj of Sitara, Chhatrasal of Panna, etc. In His book titled A history of Hindi literature, Keay (1933) writes that Chintamani Tripathi (t Intamani tripat $^{\mathrm{h}} \mathrm{i}$ ) was regarded as one of the great authorities on the subject of composition. Among his works are Chhand Bichar ( $t^{\text {h }}$ ənd bitfar), a treatise on prosody, Kavya Vivek (kawjə vivek), Kavikul Kalptaru (kavikひl kəlptəru), and Kavya Prakash (kawjə prəkaf). He was also author on Ramayana (ramajənə) in Kavitta (kəvitt) and other metres. Other brothers, especially Bhushan, also excelled in their writings and invited laurels from all across the region for their work on different aspects of literacy creativeness (Nayyar, 2012). These works, however, were mainly composed either in Hindi or Urdu, not in Kanauji.

From the perspective of linguistics, the credit of being the first modern work on Kanauji can be given to A Grammar of Modern Hindi written by S. H. Kellog, originally published in the year 1876 by Mission Press, Allahabad, India. However, his work mainly focuses on Hindi; it discusses Kanauji as a dialect of Hindi and lists only a few examples explaining its morphology and phonology. Thereafter, some other works (Tiwari, 1960; Jaiswal, 1962; Saksena, 1971; Beams, 1974; Hopper, 1977; Shapiro, 1989; Hook, 1991; Masica, 1993, Kachru, 2006), which mainly focused on Standard Hindi, such as Khari Boli, and some other eastern or western variety of Hindi also paid some attention to Kanauji. Most of these works very briefly discuss areal distribution and position of Kanauji with reference either to Standard Hindi or Eastern and Western Hindi varieties. None of these works paid any closer linguistic attention to Kanauji. In the contrary, many Eastern and Western varieties of Hindi other than Kanauji received considerable attention of the linguists despite of the fact that compared to Kanauji they can be treated as minor in terms of their speaking population and the area covered.

The first major work on Indian languages including Kanauji is Linguistic Survey of India written by George A. Grierson during 1894-1928. There are a few other works

\footnotetext{
${ }^{8}$ Different religions and Godly incarnations have left deep impact on the Indian society and its literature. Most of the literary works in the middle age were meant for praise of the Gods, king, incarnations or religions. And the two most important incarnations of Lord Vishnu, Krishna and Rama, belong to Mathura (believed to be birth place of lord Krishna and language spoken there is Braj) and Ayodhya (believed to be the birth place of lord Rama and language spoken there is Awadhi), respectively.
} 
besides, mainly representing supportive material while discussing literary works of the languages like Hindi, Awadhi and Bundeli (Trivedi, 1997, 2005), or works on NLP applications (Mishra \& Bali, 2010, 2011; Kulshreshtha, Singh \& Sharma, 2012; Kulshreshtha \& Mathur, 2012). Works on NLP applications focused mainly on Hindi spoken in Kanauji speaking region rather than Kanauji. Published locally a long time ago, several of these works are no more available. In many cases, the local publication houses that published the books have been shut down due to the lack of commercial interests. OpenLibrary.org and The Library of Congress Online Catalogue ${ }^{9}$ together have only found few works ${ }^{10}$ on Kanauji given "Kanauji, Kanauji literature or Folk literature in Kanauji" as keywords.

\section{Verbal repertoire of Kanpur}

Kanpur has been a well-known industrial and educational hub of the state of Uttar Pradesh as well as of India for a long time. It also maintains a significant stake in small and large scale business houses and agriculture. For these two reasons it attracts people from all over India visit the region, and a large number of people moved in and settled down, which enriched the region's verbal repertoire. As a result, dialects spoken are very diverse; the majority speaks either Hindi or Kanauji, or both, however people speaking Punjabi, Bengali, Marathi, Urdu, Tamil, Oriya, and other dialects of Hindi such as Braj, Awadhi, Bihari, Bhojpuri, Bagheli Bundeli, etc. are also found in large numbers (Chaturvedi, 2015). Apart from these Indian languages and dialects, urban population of Kanpur possesses good knowledge of English for the very fact that most schools offer English language as a compulsory subject on all levels of their curriculum. Apart from the state governed Uttar Pradesh Madhyamik Shiksha Parishad (a state board of secondary and higher secondary school education), two of the most popular board of school education are Indian Council of School Education (ICSE) and Central Board of Secondary Education (CBSE), where English language is used for communication primarily. And it is the same with colleges, universities, technical institutes, and research organizations. There are some institutes, colleges and universities that also offer courses in foreign languages such as French, German, Chinese, Spanish, etc. and hence, people having good knowledge of these languages can easily be found. The use of English and other foreign languages is most common indication of upper class, higher educational and professional status, stronger socioeconomic status, etc.

\footnotetext{
${ }^{9}$ The Library of Congress Online Catalog is the largest library in the world. It has millions of books, recordings, photographs, maps and manuscripts in its collections.

${ }^{10}$ Found works are listed as follows: a) Santarāma, Anila .(1975).Kanaujī loka sāhitya. Dillī : Abhinava Prakāśana; b) Tripāṭhī, Sureśa Candra (1977) Kanaujī loka sāhitya meṃ samāja kā pratibimba. Dillī : Rūpāyana Prakāśana; c) Gupta, Maheśa (1999) Loka-sāhitya kā śāstrīya anuśîlana : Bhāratīya loka-sāhitya, mukhyataḥ Pīlībhīta Janapada kā viśada adhyayana. Dillī : Śilpāyana.
} 
Chaturvedi (2015) reports that such a variety of languages and dialects used in the area of Kanpur most likely indicates one of the following three future language situations: 1) a situation completely different from the present one, 2) a situation where more than one language is knowingly used, and 3) code-mixed language situation. With such a rich confluence of languages in one place, instance code mixing and code-switching are common or even inevitable in every day life. However, long and wide-spread presence of these languages has given rise to what is popularly referred as Kanpuria Hindi. Kanpuria Hindi is based on standard Hindi but the vocabulary consists of words borrowed from Hindi, English, and other Indian languages and dialects, though a significant proportion is nevertheless from Kanauji and other Hindi dialects such as Awadhi, Bhojpuri, Bihari, Bagheli, and Bundeli. Kanpuria Hindi is a very popular medium of networking/peer talk among youth. Its usage is wide spread in everyday communication, and people mostly use it in informal conversations. Standard Hindi or English (or Hinglish) is preferred in written and formal mode of communication.

In Kanpuria Hindi, the scale of code-mixing and code-switching varies depending on the urban vs. rural class, educated vs. less-educated/illiterate class, class belonging to higher socio-economic background vs. class belonging to lower socio-economic background, etc. While code-mixing observed with the former classes is connected to well-established languages such as Punjabi, Bengali, and Marathi, the later classes generally involve other dialects of Hindi. The reason can be found in the fact that people who have migrated from other states are financially sound due to their businesses or good-profile jobs. On the other hand, people speaking Kanauji or some variety of the neighboring Hindi dialects form a major percentage of low-profile workers and people from other lower classes.

The difference is so large that we can easily devide these two forms into urban Kanpuria Hindi and rural Kanpuria Hindi respectively. Rural Kanpuria Hindi borrows heavily from Kanauji, especially its lexical, morphological, and syntactic characteristics. It is interesting that people who generally speak urban Kanpuria Hindi may shift to rural Kanpuria Hindi for a better bargain during street shopping or to show solidarity with the people. Similarly, people speaking rural Kanpuria Hindi may shift to urban Kanpuria Hindi when in a restaurant, or speaking to public servants like post-officers, policemen, doctors, etc. Such a shift may also be used in order to make fun of either their own or the other linguistic group.

\section{Present situation of Kanauji of Kanpur}

As discussed in previous sections, the language of Kanauji in its original form (as a dialect of the indigenous people in the area) has been challenged significantly due to a heavy confluence of about a dozen languages and dialects. The present situation of 
Kanauji is grave and complicated both in the urban and rural areas of the Kanpur district. While in the urban areas Kanauji has almost been replaced with Kanpuria Hindi and to a certain extent with Standard Hindi, Kanauji still functions as a mode of communication in rural areas. However, with a fast-growing educational system and urbanization, youths and children prefer speaking in Standard Hindi.

Lewis, Simons and Fennig (Ethnologue, 2013) report that despite of being a tongue of millions, Kanuaji has very low identity with no official status or proposed preservation plans. Ethnologue (2013) places Kanauji within the cloud of all living languages but in the category $6 \mathrm{~b}-7$ of the EGIDS ${ }^{11}$ scale, which reads that language in question is in trouble and intergenerational transmission of the language is in the process of being broken.

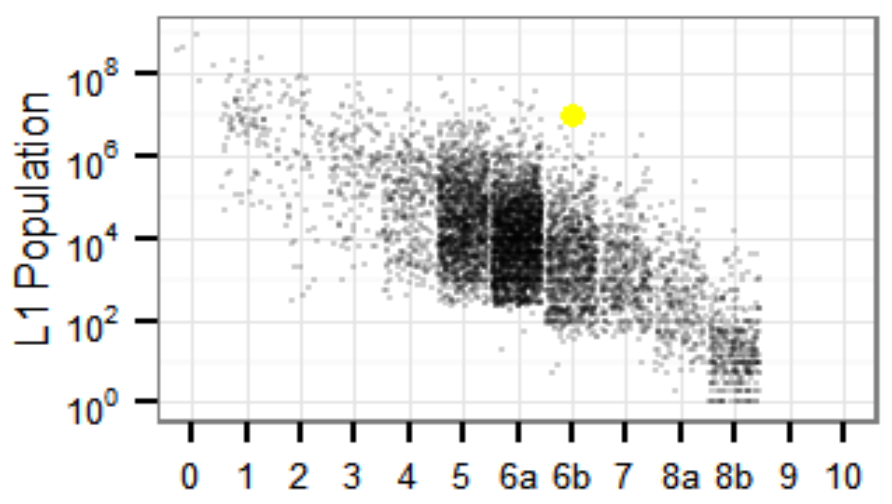

Figure 3: Yellow dot represents position of Kanauji on EDGIS Scale (taken from Ethnologue, 2013).

Despite the "troubled" situation, the child-bearing generation still uses the language. Hence, it is possible that revitalization efforts could restore transmission of the language. The scale of a given stage of endangerment in Figure 3 may be true for Kanauji in general, but not necessarily so for varieties in every part of the area. It is well-known that values on the endangerment scale may vary from EDGIS 6a to EDGIS 7) depending on sociolinguistic factors such as connectivity, education, economics, language attitude, migration, industrial development, and such, I believe, is the case with Kanauji of Kanpur; it is presently estimated at EDGIS-7. A further change of a grade would imply that the language is on the verge of extinction and could no more be restored as a form of communication. Such a fact urges us to get the language documented before it dies out.

\footnotetext{
${ }^{11}$ Ethnologue reports vitality of the languages of the world by using the Expanded Graded Intergenerational Disruption Scale or EGIDS and Graded Intergenerational Disruption Scale (GIDS) (Lewis and Simons, 2010 and Fishman's, 1991 respectively).
} 


\section{Sociolinguistic fieldwork and data collection}

During our fieldtrip to 15 villages ${ }^{12}$ of the Kanauji speaking Kanpur Nagar region with the purpose to collect speech samples ${ }^{13}$, we surveyed 80 informants to get an insight into native people's towards the use of Kanauji. The relevant details are listed below:

Table 2: Basic data of the informants in the surveyed area.

\begin{tabular}{|c|c|c|l|l|}
\hline Male & Female & Age & Education & $\begin{array}{l}\text { Bilingualism } \\
\text { (Tirhari-Hindi) }\end{array}$ \\
\hline \hline 35 & 15 & $\begin{array}{c}14-25 \\
\text { years }\end{array}$ & $10^{\text {th }}$-undergraduate & $\begin{array}{l}\text { Hindi-Kanauji unavoidably mixed. } \\
\text { Hindi is highly dominant. }\end{array}$ \\
\hline 17 & 5 & $\begin{array}{c}30-45 \\
\text { years }\end{array}$ & $\begin{array}{l}\text { Illiterate to } \\
\text { undergraduate }\end{array}$ & Kanauji is little dominant \\
\hline 5 & 3 & $\begin{array}{c}50-65 \\
\text { years }\end{array}$ & Mostly Illiterate & Kanauji is more dominant \\
\hline
\end{tabular}

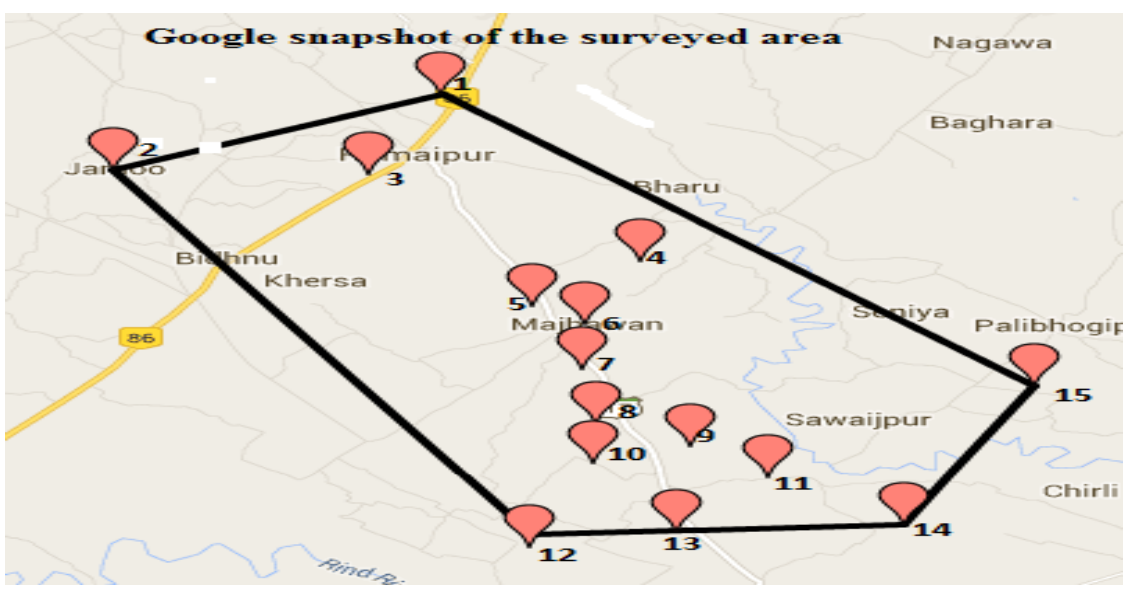

Figure 4: A snapshot of the surveyed area from the Google map.

Based on the responses of the informants, the following observations regarding language attitude of the people have been made.

12 These fifteen villages in order of visit are: 1) Gadhewa Mohasinpur, 2) Jamu, 3) Ramaipur, 4) Shahpur Majhawan, 5) Jagdishpur, 6) Majhwan, 7) ArajiMajhwan, 8) Kulhauli, 9) Hardauli, 10) Kale ka Purwa, 11) Kundauli, 12) Kaji Khera, 13) Behta Gambhirpur, 14) Rajepur, 15 ) Bhukhnahi

${ }^{13}$ We collected speech samples using two channels simultaneously: first, by Olympus LS-100 $96 \mathrm{kHz} / 24 \mathrm{PCM}$ linear recorder which is outfitted with two built-in $90^{\circ}$ stereo condenser microphones, second using Sony Digital Flash Voice Recorder -ICD-PX312. 
1. Most of high-school and university students do not even know the name of the Kanauji language - they call it either Hindi or a type of Hindi, sometimes Hindi of the uneducated people.

2. University students use standard Hindi (i.e., Khari Boli) in intra- or intergroup communication. However, they speak in Kanauji with their parents, grandparents and other older family members. They sometimes use Kanauji to look down upon or to make fun of someone, or to look funny.

3. Some youth - generally educated - admit that they feel ashamed using Kanauji in public though they are well familiar with the language. This confirms the general negative attitude of people towards Kanauji.

4. No school allows Kanauji to be used in classes, even in the areas where Kanauji speaking population is relatively large.

5. Informants aged between 10 and 35 said they do not use Kanauji in formal situations, for example if they go to see doctors, teachers, the village head, policemen, etc. On the other hand, old people said they use Kanauji and Hindi in such situations, added that they think the use of standard Hindi is more suitable in such situations.

6. None of the informants knew of any work such as books, dictionaries, newspaper or some classical literature on Kanauji.

7. Old consider such songs either as funny or as "songs of uneducated people". people know and sing folk songs in Kanauji but not the new generations. Youths and children

8. Since parents see no economic, educational or other benefits, they do not encourage the use of Kanauji among the children. They, however, emphasize the importance of using the standard Hindi and English.

The above observations were confirmed by the results obtained from a pilot study that included a smaller group of the informants.

Below is a piece of a conversation between a teacher in a primary school (language consultant A) and a data collector (a linguist). The teacher starts with a request to the data collector on whether he could help him (the teacher) to get a particular literary work from the city. After that the teacher talks about the training he (the teacher) had undergone in his school. An army man sitting nearby (language consultant B) also speaks to agree with the teacher. A look into the conversation shows how he (the teacher) switches from Kanauji to Hindi and then back to Kanauji. It is obvious that the teacher does not realize the shift and goes on talking in the same manner for around twenty minutes.

In this part of a conversation, every sentence in a dialogue is first written in Devnagri Script (marked as DS), followed by a broad IPA transcription (marked $s$ BT) of the spoken sentence. The transcription is annotated using slanted brackets $<>$ with ISO 
639-3 language codes, that is, "bjj" for Kanauji, "hin" for Hindi and "eng" for English. The meaning is given in the last line.

Example:

Language consultant 1:

a) एत्ता काम करे जैव। एत्ती चिन्हारी अपन देहे जैव । (DS)

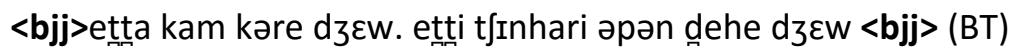

Please do this favour to me. It will remind me of you. (M)

Data Collector:

b) मैं जिस दिन घर जाँउगा, उस दिन ढूढ़ के भेज दूँगा (DS)

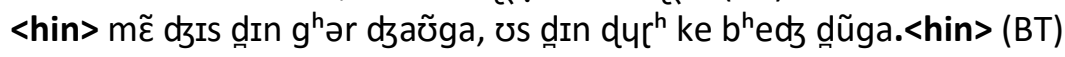

I will send it the day I reach home. (M)

Language consultant 1:

c) सात साल होइगे पढ़ावत । (DS)

$<$ bjj>sat sal horge pər ${ }^{\mathrm{h}}$ awət $<$ bjj> (BT)

I have been teaching for seven years. (M)

d) अभी जो ट्रेनिग चल रही है उसमें जब ये चीज आई तो दिमाग हमारा चकरा गया । (DS)

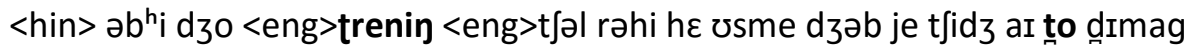

$<$ bjj> həmara <bjj>t təkra gəja.<hin> (BT)

When I came across this thing in the current training, my mind went blank. (M)

e) हेईं सासा का पढ़ै वाला लरिका आये।. नीतू का जानत है। (DS)

<bjj> hẽı sasa ka pərદ wala lərıka aje. nitu ka dzanət he. <bjj> (BT)

$\mathrm{He}$ (the trainer) comes from Sasa and knows the Neetu. (M)

f) जब उसने चालू किया तो हमनें कहीं पढ़ा था ये। दिमाग में था। लेकिन होई कुछ... (DS)

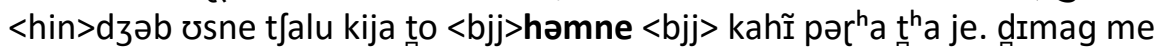

th $^{\text {h }}$ lekin $<$ hor kut $\int^{\text {h }} . . .><$ hin $>$ " (BT)

As soon as he started, I knew it as I read about it somewhere. It was on my

mind. But then, may be something..." (M)

Language consultant 2:

g) हाँ हाँ, ध्यान न दीन होइहौ (DS)

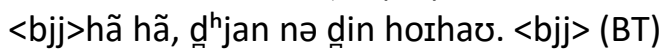

Yes, yes, you may not have paid attention. (M)

Language Consultant 1:

h) लेकिन वो बेसिक से ही आधारित है तो उसका ज्ञान आवश्यक है। (DS)

$<$ hin>lekin wo <eng>besik <eng> se hi ad harit he. to uska gjan awəsyək

he. $<$ hin> (BT)

But, it starts from basic concepts. So, it's necessary to know it. (M) 
i) ट्रेनिंग एक दिन के लिये थोड़ी न होती है। (DS) <hin><eng>trenin <eng>ek din ke Irje thori nə hotr he. <hin> (BT) Training does not help only for a day (meaning).

j) आल al larp ${ }^{h}<$ eng $>k \varepsilon$ lije hoț $h \varepsilon .<$ hin $>$ (BT) It's for a whole life. (M)लाइफ के लिये होती है. (DS) $<$ hin $><$ eng $>$

A closer look into the above conversation gives us a fair idea of how people interchangely use (code-switch and code-mix) Hindi and Kanauji in communication. In the above piece of narration, the language consultant A starts his communication (a request) using a typical Kanauji sentence (statement a) spoken in Kanpur. In response to his request, the data collector answers in Standard Hindi (statement b). However, the language consultant A goes on explaining background for his request in Kanauji (statement c) and then switching to Hindi (statement d). This pattern is repeated in sentences e and $f$, respectively. While speaking in Hindi (statement $d$ and statement $f$ ), he uses pronouns /həmara/ (meaning "I") and /to/ (meaning "then") in Kanauji. In Hindi, the correct pronouns are /m̃̃̃/ and /tab/ respectively. The language consultant $A$ is about to say something more at end of statement $f$ using Kanauji but he is cut short by the language consultant $B$, who agrees with the explanation given by language consultant $A$ (statement g) using Kanauji. Elaborating further on the situation, language consultant $A$ again speaks three more sentences in Hindi (statement $h$ to $j$ ).

Language consultant A also uses words from English such as "training", "basic" and "all" in different statements. However, these words are adapted to the phonological inventory of Kanauji and therefore their pronunciation gets changed accordingly. For example, in the statement $\mathrm{j}$ the phrase "all life" is pronounced as /al \# larph/ in contrast to / $:$ I \# larf/, as Kanauji lacks phonemes / $\mathrm{J} /$ and /f/. The word "training" which occurs in statements $i$ and $d$ is pronounced as /trenin/ instead of /treinin/. Due to the absence of phoneme / $t$ / in Kanauji, phonetically its nearest phoneme / $t$ / is adapted. A different placement of stress reduces the /ei/ into /e/.

Due to such constant code-switching and code-mixing, this piece of conversation may sound odd to native Kanauji speakers as well as Hindi speakers. During this narration, both languages consistently maintain Kanauji intonation, which can easily be recognized by a native speaker of Hindi.

\section{Comparative linguistic sketch of Kanauji and Hindi of Kanpur}

Kanauji has a few written records in Devnagari (Trivedi, 1997). Based on our 18 days of fieldwork we collected words, sentences, and free discourse samples from a range of domains such as Basic wordlist, Demographic description, Cuisine, Family communication, Games, Culture and Traditions, Flora and Fauna, Mythological stories, Daily life activities, Children stories, Number systems, Free discourse, Minimal pairs, 
Representative sentences, Group conversation, and others. A text and a speech database ${ }^{14}$ were prepared based on the collected data. The analyses of the database brought us to the following conclusions. Kanauji of Kanpur has 31 consonants, 10 native vowels and 1 foreign vowel "æ"15 in its phonemic inventory. All vowels have their respective nasalized counterpart vowels. In writing, Kanauji exhibits the same number and types of consonants as standard Hindi. However, many consonants have lost their individual pronunciation in Kanauji, which is also observed in other dialects of Hindi. Table $3 a$ shows a list of vowels, diphthongs and consonants in Kanauji of Kanpur.

Table 3a: Inventory of vowels in Kanauji of Kanpur.

\begin{tabular}{|c|c|c|c|c|c|c|}
\hline Vowels & $\mathrm{i}$ & I & e & $\varepsilon$ & $a$ & \\
\hline Nasalized vowels & $\tilde{\imath}$ & $\tilde{\mathrm{I}}$ & $\tilde{\mathrm{e}}$ & $\tilde{\varepsilon}$ & ã & \\
\hline Vowels & ə & u & $\mho$ & 0 & כ & $æ$ \\
\hline Nasalized vowels & $\tilde{\partial}$ & $\tilde{u}$ & $\tilde{\mho}$ & $\tilde{0}$ & ว & $\tilde{\not}$ \\
\hline
\end{tabular}

Mishra and Bali (2010) list a slightly different number of diphthongs found in the Kanauji (Table 3b, right). We suppose that they have taken a slightly different variety of Kanauji, the variety spoken in the district of Kanauji, though it is not clearly mentioned which variety of Kanauji they are referring to. Kanpur, on the other hand, being repertoire of different languages, majorly includes varieties of Eastern and Western Hindi, therefore the number and type of diphthongs found may show some difference. From the database we prepared, diphthongs found in the Kanauji of Kanpur are listed on the left.

Table 3b: Diphthongs in Kanauji of Kanpur.

\begin{tabular}{|c|c|}
\hline Kanauji of Kanpur & Kanauji \\
\hline 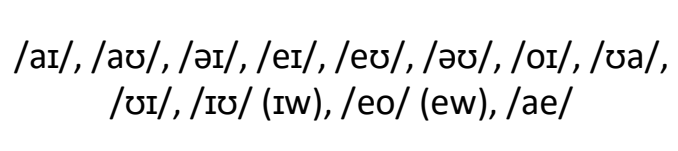 & 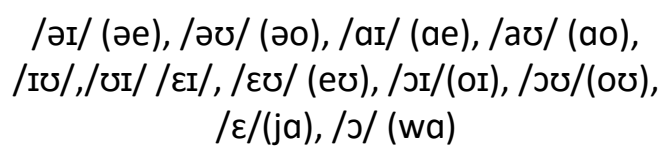 \\
\hline
\end{tabular}

\footnotetext{
${ }^{14}$ Text database mainly consists of .doc and excel files, while speech database consists of wav files. Speech database is broadly annotated using PRAAT software. A detailed discussion on the preparation or annotation of these databases is beyond the scope of this a paper.

${ }^{15}$ English words like "cat", "bat", "man", "hat", etc. are commonly understood and frequently used by Kanauji speakers (even by uneducated ones). Somehow, most of them pronounce it with correct "æ" vowel sound. This inclusion of vowel sound could be due to far reaching impact of English media over Kanauji speakers.
} 
Table 3C: Inventory of consonants in Kanauji of Kanpur.

\begin{tabular}{|l|l|c|}
\hline Plosives & $\begin{array}{l}/ \mathrm{p} / / \mathrm{p}^{\mathrm{h}} / ; / \mathrm{b} /, / \mathrm{b}^{\mathrm{h}} / ; / \mathrm{t} /, / \mathrm{t}^{\mathrm{h}} / ; / \mathrm{d} /, / \mathrm{d}^{\mathrm{h}} / ; / \mathrm{t} / / \mathrm{t}^{\mathrm{h}} / ; / \mathrm{d} /, \\
/ \mathrm{d}^{\mathrm{h}} ; / / \mathrm{k} /, \mathrm{k}^{\mathrm{h}} / ; / \mathrm{g} /, / \mathrm{g}^{\mathrm{h}} /\end{array}$ & 16 \\
\hline Nasal & $/ \mathrm{m} /, / \mathrm{n} /, / \mathrm{g} /$ & 3 \\
\hline Fricative & $/ \mathrm{s} /, / \mathrm{h} / / \mathrm{f} / *, / \mathrm{s} / * / \mathrm{v} / * / \mathrm{z} / * 16$ & $2(+4)$ \\
\hline Affricates & $/ \mathrm{t} /, / \mathrm{t}^{\mathrm{h}} / ; / \mathrm{d} /, / \mathrm{d}^{\mathrm{h}} /$ & 4 \\
\hline Laterals & $/ \mathrm{l} /$ & 1 \\
\hline Semi-Vowels & $/ \mathrm{w} /, / \mathrm{j} /$ & 2 \\
\hline Trill & $/ \mathrm{r} /$ & 1 \\
\hline Tap/Flap & $/ \mathrm{r} /, / \mathrm{r}^{\mathrm{h}} /$ & 2 \\
\hline Total & & $\mathbf{3 1 ( + 4 )}$ \\
\hline
\end{tabular}

Kanauji is a CVC type language. Kanauji of Kanpur permits all four types of syllables, the "CV", "CVC", "VC" and "V" type. Consonant clusters are not prominent, and in cases of a borrowed consonant cluster, the cluster is broken by epenthesis. A cluster of a consonant followed by a semivowel (cf. $\mathrm{C}+\mathrm{w} / \mathrm{j}$ ) is allowed in initial position to some extent. Clusters are more restricted in the coda position. Medial clusters in words usually belong to two different adjacent syllables, a coda of the preceding syllable and an onset of the following syllable respectively. An analysis of 772 words collected during the fieldwork provides us with the following results:

Table 4: An analysis of basic word list of Kanauji of Kanpur

\begin{tabular}{||l|c|}
\hline Words & Number \\
\hline \hline Words with final clusters & 9 \\
\hline Words with initial clusters & 27 \\
\hline Words with medial clusters & 192 \\
\hline Words with unbroken medial cluster & 1 \\
\hline Words with no clusters & 543 \\
\hline Total & $\mathbf{7 7 2}$ \\
\hline
\end{tabular}

\footnotetext{
${ }^{16}$ Consonants written in bold and marked with asterisk are spoken by speakers who know Standard Hindi or Urdu other than Kanauji, which is very common in Kanpur. Otherwise, these consonants are absent in native phonemic inventory of Kanauji.
} 
Initial Consonant Clusters: $r j, k w, k^{h} w, g w, g^{h} w, g j, t f w, t 5 w, d z w, d 3^{h} w, t w, t j, t^{h} w, t j$, $d w, d j, d^{h} w, d^{h} j, d w, d j, d^{h} w, n j, n w, p w, p j, p^{h} w, p^{h} j, b w, b j, b^{h} w, b^{h} j, l w, l j, s w, s j, h w$, $h j, k j, k^{h} j, k r, d^{h} r, p r, s r, b r$ and (sl, bl, kl, tr, wy). ${ }^{17}$

Medial Consonant Clusters: $b-b, d-d^{h}, d-m, d-r, d-r, d-w, d z-d z, d z^{h}-r, d z-c, d z-r, d-d^{h}, d-d$ $p^{h}-t, g-d 3, g-g, g-g^{h}, g-r, h-k, h-l, h-r, h-r, h-s, k-k, k-l, k-m, k-n, k-r, k-s, k-t, k-w, I-d, l-l$, I-m, I-n, I-r, I-s, I-s, I-w, m-b, m-b, m-k, m-l, m-m m-n, m-p ${ }^{h}, m-s$ m-t,m-t, m-t, n-d, n-d, $n-d, n-d z, n-d, n-g, n-k, n-n, n-p, n-r, n-t, n-t \int, n-w, n-r, p^{h}-c, p-p, p-r, p-s, r-b, r-d, r-d, r-$ $\mathrm{d}, r-\mathrm{d} 3, r-\mathrm{g}, \mathrm{r}^{\mathrm{h}}-\mathrm{w},[r j], r-k, r-r, r-s, r-\mathrm{t}, r-\mathrm{t} \int, r-w, r-w, s-d 3, s-k, s-m, s-n, s-r, s-s, s-t, t-b, t^{\mathrm{h}}-$ $k, t-k, t-k, t-n, t-k, t-l, t-r, t-t f, t-t, t-t-t^{h}, t-w, t-t, t-t, t-w$

Final Consonant Clusters: $\mathrm{dd}_{\mathrm{f}^{\mathrm{h}}}, \mathrm{lh}, \mathrm{nd}, \mathrm{nd} 3, \mathrm{rr}, \mathrm{t} \mathrm{t}^{\mathrm{h}}, \mathrm{pp}, \mathrm{Il}, \mathrm{kk}, \mathrm{mm}, \mathrm{tt}$,

Some other examples of the differences and similarities of Kanauji compared to Hindi are:

A. Kanauji of Kanpur does not distinguish between a voiceless palatal sibilant consonant / $/$ / and a voiceless dental sibilant /s/. Usually, /s/ is preferred in all positions of the words (initial, medial or final). Examples:

$\begin{array}{lll}\text { Hindi } & \text { /sadi/ "plain" } & \text { /Jadi/ "marriage" } \\ \text { Kanauji } & \text { /sadi/ "plain" } & \text { /sadi/ "marriage" }\end{array}$

B. A voiced dental sibilant / $\mathrm{z} /$ and a voiceless fricative /f/ are absent from the consonant inventory of Kanauji of Kanpur and therefore they are usually pronounced as a voiced palatal affricate/dz/ and aspirated voiceless bilabial stop/ph $/$ respectively. Examples:

$\begin{array}{lll}\text { Hindi } & \text { /saf/"clean" } & \text { /zəhər/ "poison" } \\ \text { Kanauji } & \text { /saph" "clean" } & \text { /dzəhər/ "poison" }\end{array}$

C. The h-elision can be observed in many cases. Though h-elision primarily looks sporadic in nature, it needs to be determined if there is some specific phonological environment for this phenomenon.

D. In some places semivowels / $\mathrm{j} /$ and /w/ are replaced with a voiced palatal affricate/dz/ and a voiced bilabial stop /b/ respectively. Examples:

$\begin{array}{lll}\text { Hindi } & \text { /somwar/ "Monday" } & \text { /jəmona/ "river Yamuna" } \\ \text { Kanauji } & \text { /sombar/ "Monday" } & \text { /dzəmona / "river Yamuna" }\end{array}$

\footnotetext{
${ }^{17}$ Clusters in bold are found in the words which are borrowed from other languages such as Hindi and English and are in frequent use in Kanauji of Kanpur.
} 
E. Rhotacism: / / is replaced by $/ \mathrm{r} /$ in intervocalic and in final positions if preceded by a vowel. Like in many other languages, such rhotacism is sporadic and frequent exceptions are found. Examples:

$$
\begin{array}{lll}
\text { Hindi } & \text { /hərrjali/ "greenery" } & \text { /badal/ "cloud" } \\
\text { Kanauji } & \text { /harrjari/ "greenery" } & \text { / badər / "cloud" }
\end{array}
$$

F. Lexical Similarity: According to Lewis, Simons and Fennig (2013), lexical similarity between Kanauji and Hindi measures around $83 \%-94 \%$. However, it is not clear which variety of the Kanauji is mentioned there. It is further claimed that $84 \%-97 \%$ similarity is found between all varieties of Kanauji, which may be true if influence of fastspreading Hindi is ignored and only native vocabulary is compared. A comparative list of ten words of Kanauji and Hindi are given below.

\begin{tabular}{|c|c|c|}
\hline Words & Hindi & Kanauji \\
\hline Finger & vngli & ãgu.ri \\
\hline Eye & $\tilde{a} k^{h}$ & $\tilde{a}^{h^{h}}$ \\
\hline White & vdzla & vdzər \\
\hline Twenty one & ikkis & ekəIs \\
\hline How & kese & kəIse \\
\hline Farms & $k^{h} e t$ & $k^{h} e t / k^{h} e t w a$ \\
\hline Kitchen & tulha & tulh \\
\hline Peel & $t^{\text {th } I l k a}$ & $\mathrm{t}^{\mathrm{h}} \mathrm{Ikla} /$ bokla \\
\hline Gods & devta & devta \\
\hline Marriage & bjah & braw/brjaw \\
\hline
\end{tabular}

Table 5: Comparison between Hindi and Kanauji words

\section{Factors causing the decline of Kanauji in Kanpur}

Factors causing the decline of Kanauji are given as follows:

1. The district of Kanpur has been hub to industries and business for a long time and in the last few decades it has emerged as one of the most important centers of education in the state of Uttar Pradesh. People have therefore shifted to either Kanpuria Hindi or to standard Hindi for intergroup communication. 
2. Medium of instructions in schools, colleges and universities is standard Hindi, or English in few cases, but not Kanauji. Hence, Kanauji does not cater to educational or professional needs of children and youths.

3. Standard Hindi is considered to be more prestigious.

4. Hardly any literature is written in or about Kanauji. The one that exists is restricted to show the language only as a part of the history of the Hindi language. Therefore, people may not find themselves attached to the language. Besdies, the lack of written literature deprives the language from being included as a teaching material in schools.

5. Religion plays a very important role in preserving either language or culture (Fellman, 1973). Kanauji has little religious grounding, especially compared to Awadhi, a neighboring Eastern Hindi dialect, which connects itself to Hindu religion and enjoys all the prestige.

\section{Conclusion}

The state of Kanauji (and therefore its language, Kanauji, too) has been a witness to one of the most prospective periods in the Indian history (Tripathi, 1989; Majumdar, 1951, 1955; Smith, 1908). Today, however, its native language lacks attention due to socio-political reasons.

Lack of attention to a dialect in comparison to other major and official languages is a common habit among the bureaucratic policies across the world, though not among linguists and other academics, writers, or language activists. Sadly enough, a close look at Kanauji reveals that despite it being a mother tongue of six million people, it has been ignored by both groups alike. Ironically, tens of languages in India and hundreds of languages across the world, which are far smaller in terms of their area and speaking population, have been documented, promoted and worked upon. As a result, some of these languages got not only saved from extinction but also promoted among community members and scholars.

Kanauji needs good documentation, reinvigoration and promotion efforts done in cooperation by linguists, officials and community members. There is also a dire need to collect data on Kanauji such as multipurpose speech and text corpora, language teaching materials, language technology application, etc. An active and positive role of print and electronic media can also help Kanauji regain its prestige and consequently reclaim its speakers.

In the present state of sheer indifference, Kanauji is being rapidly devoured by its neighboring languages and Standard Hindi, heading to what may be called a death of a major language (Khokhlova, 2014). For that reason it is of great importance to document and start promoting it immediately. 


\section{Acknowledgement}

Authors acknowledge the kind support of their language consultants during data collection. Pankaj Dwivedi acknowledges Indian Institute of Technology Ropar for providing fellowship and funds for fieldwork and purchase of required equipment such as Olympus LS-100 96kHz/24 PCM linear recorder and tripods.

\section{References}

Beams, J. (1974). Outlines of Indian philology with a map shewing the distribution of Indian languages. New Delhi: Today and Tomorrow Printers and Publisher

Bhatia, T. K. (1987). A history of the Hindi grammatical tradition: Hindi-Hindustani grammar, grammarrians, history and problems (Handbuch Der Orientalistik, Vol 4). Leiden: The Netherlands.

Chaturvedi, S. (2015). A Sociolinguistic study of linguistic variation and code matrix In Kanpur. Procedia-Social and Behavioral Sciences, 192, 107-115.

Fellman, J. (1973). Concerning the 'revival' of the Hebrew language. Anthropological Linguistics, 15. 250-257.

Grierson, G. A. (eds.). (1916). Linguistic survey of India. Vol. 9. Kolkata: Superintendent Government Printing.

Hook, P. E. (1991). The emergence of perfective aspect in Indo-Aryan languages. In Elizabeth C. Traugott \& Bernd Heine (eds.) Approaches to grammaticalization, 2, 5989. Amsterdam: John Benjamins Publishing

Hopper, P. J. (eds.). (1977). Studies in descriptive and historical linguistics: Festschrift for Winfred P. Lehmann. Vol. 4. Amsterdam: John Benjamins Publishing Company.

Jaiswal, M. P. (1962). A linguistic study of Bundeli (Vol. 8). Brill Archive.

Kachru, Y. (eds.). (2006). Hindi. Amsterdam/Philadelphia: John Benjamins Publishing Company.

Keay, F. E. (1920). A history of Hindi literature. Mysore City: Wesleyan Press

Khokhlova, L. V. (2014). Majority language death. In: Hugo C. Cardoso (eds.), Language endangerment and preservation in South Asia. 19-45. Honolulu: University of Hawai'i Press.

Kulshreshtha, M. and Mathur, R. (2012). Hindi language and its dialects. In: Dialect accent features for establishing speaker identity, 15-20. New York: Springer-Verlag:

Kulshreshtha, M.; Singh, C. P. and Sharma, R. M. (2012). Speaker profiling: The study of acoustic characteristics based on phonetic features of Hindi dialects for forensic speaker identification. In: Amy Neustein \& Hemant A. Patil (eds.), Forensic speaker recognition: Law enforcement and counter-terrorism, 71-100. New York. Springer 
Lewis, P. M., Simons, G. F. and Fennig, C. D. (eds.). (2013). Ethnologue: languages of the world, seventeenth edition. Dallas-Texas: SIL International. Online version: http://www.ethnologue.com.

Majumdar, R. C. (1955). The Age of imperial Kanauj .vol. 4. Mumbai: Bharatiya Vidya Bhavan.

Manuel, P. L. (1989). Thumrī in historical and stylistic perspectives. New Delhi: Motilal Banarsidass Publications.

Masica, C. P. (1993). The Indo-Aryan languages. Cambridge: Cambridge University Press.

Mishra, D. and Bali, K. (2010). Hindi dialects phonological transfer rules for verb root Cala. Paper presented at $13^{\text {th }}$ oriental COCOSDA-2010 conference in coordination with International Committee for the Co-ordination and Standardization of Speech Databases and Assessment Techniques held at Kathmandu. Nepal, 24-25 November

Mishra, D. and Bali, K. (2011). A Comparative phonological study of the dialects of Hindi. Paper presented at The 17th International Congress of Phonetic Sciences (ICPhS XVII), Hong- Kong, China, 17-21 August

Narula, S. S. (1955). Scientific history of the Hindi language. New Delhi: Hindi Academy.

Nayyar, S. (2002). History of Hindi. Retrieved from http://www.esamskriti.com/essaychapters/History-of-Hindi-1.aspx on June 20, 2014.

Saksena, B. (1971). Evolution of Awadhi: A branch of Hindi. Vol. 12. New Delhi: Motilal Banarsidass Publisher.

Shapiro, M. C. (1989). A primer of modern standard Hindi. New Delhi: Motilal Banarsidass Publishers

Smith, V. A. (1908). The history of the city of Kanauj and of king Yasovarman. The Journal of the Royal Asiatic Society of Great Britain and Ireland, 765-793.

Tiwari, U. (1960). The origin and development of Bhojpuri. Kolkata. The Asiatic Society

Tripathi, R. S. (1989). History of Kanauj: To the moslem conquest (Vol. 11). New Delhi: Motilal Banarsidass Publisher.

Trivedi, G. M. (1997). Ganga ke nichle doab ka bhasha sarvekshan. Kolkata: Anthropological Survey of India Press

Trivedi, G. M. (1990). Eco formation. In Krishnan, Shree (eds.), Linguistic traits across language boundaries, 51-82. Calcutta: Anthropological Survey of India

Upadhyaya, A. S. (1934). The origin and growth of Hindi language and its literature. Patna: Patna University. 